\title{
THE EU'S USAGE OF POLITICAL CONDITIONALITY FOR DEMOCRATIZATION: AN ASSESSMENT FOR CANDIDATES AND ENP'S SOUTHERN PARTNERS
}

\author{
Uğur Burç YILDIZ*
}

\section{Abstract}

This article, by applying the ratings of Freedom House, analyzes the effectiveness of the European Union's usage of political conditionality for the democratization of the former and current candidate countries, and Southern partner countries in the European Neighborhood Policy. Political conditionality is the European Union's main strategy to democratize candidate countries. Due to the effectiveness of European Union's political conditionality all former candidates were labeled by Freedom House as liberal democracies before starting accession negotiations with the European Union. The European Union's usage of political conditionality with current candidates has led to democratization of many practices, such as the protection of human rights, minority rights and different cultures. This success is mainly the result of the European Union's membership incentive and, in case of non-compliance, the possibility of high domestic costs for candidates. The European Union has also used political conditionality to democratize its Southern partner countries through its European Neighborhood Policy. However, due to the lack of a membership incentive and domestic costs for these countries, political conditionality has not led to democratization, as clearly shown in Freedom House ratings for these countries since the introduction of the European Neighborhood Policy in 2004.

Keywords: Political Conditionality, Democratization, Candidate Countries, the European Neighborhood Policy, Southern Partner Countries

\section{AB'NIN DEMOKRATIKLEŞME İÇİN SIYYASI KOŞULLULUĞU KULLANMASI: ADAYLAR VE AVRUPA KOMŞULUK POLITTIKASI'NIN GÜNEYLİ ORTAK ÜLKELERİ İÇİN BİR DEĞERLENDİRME $\ddot{O} z$}

Bu makalede, Özgürlükler Evi'nin puanlarına başvurulara keski ve günümüzdeki aday ülkelerde ve Avrupa Komşuluk Politikası'ndaki Güneyli ortak

\footnotetext{
*Asst. Prof. (PhD), Izmir University, Faculty of Economics and Administrative Sciences, Department of International Relations, e-mail: burc.yildiz@izmir.edu.tr
} 
ülkelerde Avrupa Birliği'nin siyasi koşulluluk stratejisinin demokratikleşmeye olan etkisi analiz edilmektedir. Siyasi koşulluluk Avrupa Birliği'nin aday ülkeleri demokratikleştirmede kullandiğg temel stratejisidir. Avrupa Birliği'nin siyasi koşulluluğu etkin bir şekilde kullanmasından dolayı eski aday ülkeler katılım müzakerelerine başlamadan önce Özgürlükler Evi tarafindan liberal demokrasiler olarak tanımlanmışlardır. Avrupa Birliği’nin günümüzdeki aday ülkeler üzerinde siyasi koşulluluğu kullanması neticesinde de bu ülkelerde örneğin insan haklarl, azınlık hakları ve farklı kültürlerin korunması gibi birçok uygulamada demokratikleşme sağlanmıştır. Esas itibariyle, Avrupa Birliği'nin bu başarışı siyasi koşulluluğa riayet göstermeleri durumunda aday ülkelere sunduğu üyelik teşviki ve riayet göstermemeleri durumunda ise bu ülkelerde ortaya çıkabilecek iç siyasi maliyetlerden kaynaklanmaktadır. Avrupa Birliği, siyasi koşulluluğu Avrupa Komşuluk Politikası'ndaki Güneyli ortak ülkeler için de kullanmaktadır. Ancak, bu ülkelere üyelik teşviki verilmemesi ve iç siyasi maliyetler riskinin bulunmaması nedeniyle Özgürlükler Evi'nin puanlarında görüldüğü üzere siyasi koşulluluk bu ülkelerde demokratikleşmeye yol açmamaktadır.

Anahtar Kelimeler: Siyasi Koşulluluk, Demokratikleşme, Aday Ülkeler, Avrupa Komşuluk Politikası, Güneyli Ortak Ülkeler

\section{Introduction}

Since the end of the Cold War, the European Union (EU), like other international actors, such as the Council of Europe, the North Atlantic Treaty Organization, the Organization for Security and Co-operation in Europe (OSCE) and the United States, has increased its efforts to promote democratization. The EU has used political conditionality as its main strategy to promote democratization in both former and current candidate countries, and partner countries in the European Neighborhood Policy (ENP). This paper investigates the effectiveness of EU political conditionality on former candidates from Central and Eastern European Countries (CEECs) ${ }^{1}$ which joined the EU in 2004 and 2007, Croatia, ${ }^{2}$ current candidates $^{3}$ and ENP's Southern partners ${ }^{4}$. For this analysis, this study draws on the freedom ratings of Freedom House, the leading organization for the measurement of democracy levels. The paper, firstly, argues that the EU very

\footnotetext{
${ }^{1}$ In this paper, CEECs refer to the countries which joined the EU in 2004, namely Czech Republic, Estonia, Hungary, Latvia, Lithuania, Poland, Slovakia and Slovenia, and in 2007, namely Bulgaria and Romania.

${ }^{2}$ Croatia, which joined the EU in 2013 , is indeed geographically among CEECs. However, due to the EU mainly targeted CEECs with the 2004 enlargement, and as part of it with the 2007 enlargement, this paper does not put Croatia among CEECs while making its analysis regarding democratization.

${ }^{3}$ Current candidate countries are Turkey, Iceland, Montenegro and Macedonia. However, this paper excludes Iceland from its analysis on account of this country's advanced liberal democratic status before applying to EU for membership.

${ }^{4}$ This paper takes into account ENP's Southern partners as which the EU has implemented Action Plans. These are Egypt, Israel, Jordan, Lebanon, Morocco, Occupied Palestinian Territory and Tunisia.
} 
effectively promoted democratization in the CEECs through political conditionality after the introduction of the Copenhagen political criteria in 1993, enabling it to achieve the democratization of many practices, such as the protection of human rights, minority rights and different cultures, in the current candidates. This success has stemmed from the membership incentive (including the threat of exclusion from EU membership) for candidate countries to demonstrate compliance with EU political conditionality, and high domestic costs, such as the loss of power of ruling governments, in case of non-compliance. It is worth mentioning that the EU's contribution to democratization in Europe, including former and current candidate countries, was one of the main reasons why it was awarded the Nobel Peace Prize in 2012 (Nobel Prize, 2012).

On May 1, 2004, the EU experienced the biggest enlargement in its history, with the accession of eight CEECs, Malta and Greek Cypriots ${ }^{5}$. This enlargement gave the EU new neighbors on its external land and sea borders, namely Southern Mediterranean countries, Western NIS (Belarus, Moldova and Ukraine) and Russia. In order to avoid various threats, such as international terrorism and illegal immigration, related with these new neighbors, the EU had to achieve regional and sub-regional cooperation and integration with them, aiming at ensuring political stability, enhancing economic development and reducing poverty. Thus, the EU created the ENP in 2004. As envisaged by the EU, one of the most significant dimensions of the ENP was stimulating democratization in partner countries. To do this, the EU decided to apply political conditionality. However, as this paper shows, the Freedom House ratings demonstrate that the EU has not achieved any gains on this issue in case of its Southern partners since the introduction of the ENP. Some of the reasons for this failure were in fact previously predicted by Schimmelfennig in 2005 (Schimmelfennig, 2005a: 3). Firstly, the EU has not offered any membership incentive to these countries in exchange for making democratization reforms. Secondly, although authoritarian governments in these countries have been unwilling to introduce democratization reforms, they have not faced high domestic costs.

It is worth mentioning that these reasons explaining the EU's failure with the ENP's Southern partners do not apply to the ENP's Eastern partners, which are therefore excluded from the assessment given in this paper. The first reason for this difference is that, in contrast to its refusal to offer the incentive of EU membership incentive to Southern partners, the EU has neither promised nor precluded the prospect of membership for the countries involved in the Eastern Partnership $(\mathrm{EaP}),{ }^{6}$ introduced under the ENP framework in 2009. Currently Moldova, Georgia, which have introduced democratization and free market reforms, and Ukraine, which has struggled to integrate with the EU in spite of Russian pressure,

\footnotetext{
${ }^{5}$ As part of this wave of enlargement, Bulgaria and Romania joined the EU on January 1, 2007, as well.

${ }^{6}$ The EaP is directed at six countries: Armenia, Azerbaijan, Belarus, Georgia, Moldova and Ukraine. It aims to support their political, economic and institutional reforms in line with the EU standards, facilitate their trade relations with the EU, and increase the international mobility of their people.
} 
discuss to apply for EU membership. In April 2014, the European Parliament (EP) recognized, through a non-legislative resolution, Moldova, Georgia and Ukraine's right to join the EU if they comply with conditions for candidate status. Specifically, the EP's resolution states that "pursuant to Article 49 of the Treaty on the European Union, Georgia, Moldova and Ukraine - like any other European state - have a European perspective and may apply to become members of the Union provided that they adhere to the principles of democracy, respect fundamental freedoms and human and minority rights and ensure the rule of law" (Europe without Barriers, 2014). The second reason for differences in the EU's effect on ENP and EaP partners is that the argument about the lack of domestic costs does not apply to EaP countries, as seen in Ukraine, where Ukraine President Viktor Yanukovych's rejection of the EU's Association Agreement in November 2013 led to bloody events in the country.

This paper begins by explaining the EU's perception of democracy that it has wished to impose through political conditionality on former and current candidates, and ENP partners. The second section applies Freedom House ratings to evaluate the effectiveness of EU political conditionality on former and current candidates. The third section applies the same method to the ENP's Southern partners. The conclusion makes a general evaluation of the study and provides some recommendations for the EU regarding how it can more effectively promote democratization in current candidates and ENP's Southern partners.

\section{The EU's Perception of Democracy and Political Conditionality}

Defining democracy is challenging because there is no universally accepted definition. One method is to define it as the fulfillment of free and fair elections. Usually applied during the Cold War years, this minimalist method, known as electoral democracy, is strongly criticized by current scholars who define it in a maximalist manner, as liberal democracy (Y1ld1z, 2012: 285). One prominent liberal scholar studying democracy and democratization, Larry Diamond, argues that liberal democratic values include "vigorous rule of law with an independent and nondiscriminatory judiciary; extensive individual freedoms of belief, speech, publication, association, assembly, and so on; strong protections for the rights of ethnic, cultural, religious, and other minorities; a pluralistic civil society, which affords citizens multiple channels outside of electoral arena through which to participate and express their interests and values; and civilian control of the military" (Diamond, 2003: 8; 1999: 10-12).

According to Diamond the liberal democratic values are effectively measured by Freedom House through its annual publication of the "Freedom in the World" report (Diamond, 1999: 12). Freedom House, which has significant international prestige, has been assessing global political rights and civil liberties in its reports since 1972. These reports provide political rights ratings based on the evaluation of electoral processes, political pluralism and participation and government functioning. Civil liberties are evaluated in terms of freedom of expression and 
belief, associational and organizational rights, rule of law, and personal autonomy and individual rights. The reports give separate numerical ratings from 1 to 7 for political and civil liberties in each country, where 1 represents the most free and 7 the least free. The overall status of countries is defined as the average of the scores for political rights and civil liberties in three bands: Free (1.0 to 2.5), means a country is a liberal democracy, Partly Free (3.0 to 5.0), or Not Free (5.5 to 7). The survey ratings of Freedom House are very valuable, and used by political scientists, human rights defenders, international organizations, civil activists and policy makers worldwide. As Fareed Rafiq Zakaria rightfully points out, "while there are many sources of economic data, good political data is hard to find. Freedom House's survey is an exception. For anyone concerned with the state of freedom, or simply with the state of the world, Freedom in the World is an indispensable guide" (Freedom House, 2012a: 38). The ratings of Freedom House are so influential that the authoritarian leaders in some countries feel the need to issue statements defending the legitimacy of their political regimes against the ratings.

The most effective way for international actors to promote democratization is through conditionality, whereby, if states adopt and maintain certain programs, they earn the right to receive political support, economic aid or membership of an organization (Kubicek, 2003: 7). Political conditionality in true sense emerged after the end of the Cold War to democratize the CEECs. (Stokke, 1995: 9), with the EU being the most important actor through its liberal perception of democracy that it was able to impose on them applying for EU membership (Schimmelfenning, 2005b: 29). Likewise today, candidates have to adopt the EU's liberal democratic values in order to gain membership. The EU has also tried to democratize its ENP partner countries in line with these liberal democratic values. As we will see, however, in the following sections, whereas the EU successfully democratized its former candidate countries and has achieved the introduction of many democratic practices in current candidates in line with its liberal democratic perception of democracy, it has not succeeded in democratizing the ENP's Southern partners because its policy lacks any EU membership incentive and the governing regimes of these partner countries have not suffered domestic costs from non-compliance.

\section{The Effectiveness of Political Conditionality on Former and Current EU Candidates}

The EU first used political conditionality in rejecting Spain's application for membership. The Birkelbach Report, adopted by the European Parliament in 1962 in response to Spain's application, stated that membership of the European Economic Community ${ }^{7}$ was only open to truly democratic countries (Kubicek,

\footnotetext{
${ }^{7}$ The Merger Treaty, which came into force on 1 July 1967, created a single set of institutions for three communities, namely the European Economic Community, European Coal and Steel Community, European Atomic Energy Agency, which were collectively referred to as the European Communities, although commonly just as the European Community. With the came into force of the Treaty on European Union (the Maastricht Treaty) on November 1, 1993, the name European Community became the European Union.
} 
2003: 8). In 1993, with the adoption of the Copenhagen Political Criteria, which stipulate that EU membership requires "stability of institutions guaranteeing democracy, the rule of law, human rights and respect for and protection of minorities" (European Council, 1993: 13), the EU powerfully began to impose political conditionality on CEECs. After taking the positive opinion of the European Commission, the enlargement process started with the Luxembourg European Council summit of December 12-13, 1997, when leaders of EU Member States reiterated that alignment with the Copenhagen political criteria was a precondition for opening accession negotiations with a candidate country. In Luxembourg, the EU decided to begin negotiations with several CEECs that had fulfilled the political criteria: the Czech Republic, Estonia, Hungary, Poland and Slovenia. At the Helsinki European Council summit of December 10-11, 1999, EU leaders decided to open accession negotiations with the remaining CEECs: Latvia, Lithuania, Slovakia, Bulgaria and Romania. The introduction of Progress Reports for CEECs then became the EU's key instrument for assessing and directing these countries democratization.

The EU effectively imposed political conditionality on the CEECs. One of the main reasons why it was effective was the combination of the EU's promise of membership coupled with its threat of exclusion. Another important reason was that these countries' governments were well aware that non-compliance with EU political conditionality could carry domestic costs, generally for the government, but also for the security and integrity of the country. In this respect, for instance, one of the major reasons behind the electoral defeat of authoritarian governments in Romania (1997), Slovakia (1998) and Croatia (2000) was these governments' unwillingness to make democratization reforms (Schimmelfenning, 2005b: 29).

Table 1: Freedom House Ratings for the CEECs (2004 Enlargement)

\begin{tabular}{|c|c|c|c|c|c|c|c|c|c|c|c|c|c|c|}
\hline $\begin{array}{l}\text { Candidate } \\
\text { Country* }\end{array}$ & $\bar{\sigma}$ & ڤ̆ & 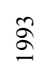 & ¿े & $\cong$ & 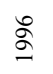 & $\hat{\sigma}$ & $\stackrel{\infty}{\curvearrowright}$ & ڤ & 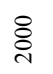 & ¿্ণ & §ิ & ڤ̊̀ & 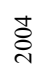 \\
\hline $\begin{array}{l}\text { Czech } \\
\text { Republic }\end{array}$ & - & - & 1.5 & 1.5 & 1.5 & 1.5 & 1.5 & 1.5 & 1.5 & 1.5 & 1.5 & 1.5 & 1.5 & 1.5 \\
\hline Estonia & 2.5 & 3 & 2.5 & 2.5 & 2 & 1.5 & 1.5 & 1.5 & 1.5 & 1.5 & 1.5 & 1.5 & 1.5 & 1.5 \\
\hline Hungary & 2 & 2 & 1.5 & 1.5 & 1.5 & 1.5 & 1.5 & 1.5 & 1.5 & 1.5 & 1.5 & 1.5 & 1.5 & 1.5 \\
\hline Latvia & 2.5 & 3 & 3 & 2.5 & 2 & 2 & 1.5 & 1.5 & 1.5 & 1.5 & 1.5 & 1.5 & 1.5 & 1.5 \\
\hline Lithuania & 2.5 & 2.5 & 2 & 2 & 1.5 & 1.5 & 1.5 & 1.5 & 1.5 & 1.5 & 1.5 & 1.5 & 1.5 & 1.5 \\
\hline Poland & 2 & 2 & 2 & 2 & 1.5 & 1.5 & 1.5 & 1.5 & 1.5 & 1.5 & 1.5 & 1.5 & 1.5 & 1.5 \\
\hline Slovakia & - & - & 3.5 & 2.5 & 2.5 & 3 & 3 & 2 & 1.5 & 1.5 & 1.5 & 1.5 & 1.5 & 1.5 \\
\hline Slovenia & 2.5 & 2 & 1.5 & 1.5 & 1.5 & 1.5 & 1.5 & 1.5 & 1.5 & 1.5 & 1.5 & 1.5 & 1 & 1 \\
\hline
\end{tabular}

Source: (Freedom House, 2014a)

* Malta and Greek Cypriots are excluded from this table as they are not CEECs. It should be noted, however, that both of these countries were defined by Freedom House as the most free before the determination of the Copenhagen political criteria in 1993. 
As can be seen from Table 1, all acceding CEECs of the 2004 group, except the Czech Republic and Hungary, whose ratings remained the same (and satisfactory) between 1993 and 2004, managed to improve their freedom ratings after the introduction of the Copenhagen political criteria in 1993. Importantly, before the EU started accession negotiations, without exception, all of them were liberal democracies according to Freedom House. Among them, however, the EU was particularly successful in Estonia, Latvia and Slovakia. As it is put by the EU, each candidate country is obligated to strengthen its democracy in line with liberal democratic values before the start of accession negotiations if it aims to become a full member of the EU (Schimmelfenning, 2005b: 29). Faced with EU political conditionality, these three countries, only defined as Partly Free by Freedom House before the imposition of the Copenhagen political criteria, became liberal democracies before the EU started accession negotiations. As part of the 2004 enlargement wave, the two CEECs, Bulgaria and Romania, whose membership applications were rejected by the EU in 2004, became members on January 1, 2007, after completing the required reforms in their judicial systems and anticorruption efforts. While the EU effectively promoted democratization in both countries, the Romanian case deserves more attention here. As seen in Table 2 below, while Romania was defined as a Partly Free country before the EU introduced the Copenhagen political criteria in 1993, it had become a liberal democracy with a Freedom House score of 2.5 by 1996, a year before the EU's adoption of Agenda 2000, in which the European Commission recommended the European Council to open accession negotiations with Romania alongside the other CEECs.

Table 2: Freedom House Ratings for Bulgaria and Romania (2007 Enlargement)

\begin{tabular}{|l|c|c|c|c|c|c|c|c|c|}
\hline $\begin{array}{l}\text { Candidate } \\
\text { Country }\end{array}$ & $\mathbf{1 9 9 1}$ & $\mathbf{1 9 9 2}$ & $\mathbf{1 9 9 3}$ & $\mathbf{1 9 9 4}$ & $\mathbf{1 9 9 5}$ & $\mathbf{1 9 9 6}$ & $\mathbf{1 9 9 7}$ & $\mathbf{1 9 9 8}$ & $\mathbf{1 9 9 9}$ \\
\hline Bulgaria & 2.5 & 2.5 & 2 & 2 & 2 & 2.5 & 2.5 & 2.5 & 2.5 \\
\hline Romania & 5 & 4 & 4 & 3.5 & 3.5 & 2.5 & 2 & 2 & 2 \\
\hline $\begin{array}{l}\text { Candidate } \\
\text { Country }\end{array}$ & $\mathbf{2 0 0 0}$ & $\mathbf{2 0 0 1}$ & $\mathbf{2 0 0 2}$ & $\mathbf{2 0 0 3}$ & $\mathbf{2 0 0 4}$ & $\mathbf{2 0 0 5}$ & $\mathbf{2 0 0 6}$ & $\mathbf{2 0 0 7}$ & \\
\hline Bulgaria & 2.5 & 2 & 1.5 & 1.5 & 1.5 & 1.5 & 1.5 & 1.5 & \\
\hline Romania & 2 & 2 & 2 & 2 & 2.5 & 2 & 2 & 2 & \\
\hline
\end{tabular}

Source: (Freedom House, 2014a)

Croatia applied for EU membership on February 21, 2003. As a result of the positive opinion of the European Commission, the European Council gave candidate status to Croatia in June 2004. In December 2004, the European Council promised to start accession negotiations on March 17, 2005, so long as Croatia was fully cooperating with the International Criminal Tribunal for the former Yugoslavia (ICTY). However, the lack of Croatian progress on this issue meant 
that the starting date of negotiations was postponed. Then, after the Chief Prosecutor of the ICTY gave a positive report on Croatia's cooperation, negotiations officially started on October 3, 2005, before being successfully completed for the parties to sign the Accession Treaty on December 9, 2011. Following the ratification of the agreement in Croatia and all EU members, Croatia joined the EU on July 1, 2013 (Delegation of the European Union to Croatia, 2013).

Table 3: Freedom House Ratings for Croatia (2013 Enlargement)

\begin{tabular}{|l|c|c|c|c|c|c|c|c|c|c|c|}
\hline $\begin{array}{c}\text { Candidate } \\
\text { Country }\end{array}$ & 1991 & $\mathbf{1 9 9 2}$ & $\mathbf{1 9 9 3}$ & $\mathbf{1 9 9 4}$ & $\mathbf{1 9 9 5}$ & $\mathbf{1 9 9 6}$ & $\mathbf{1 9 9 7}$ & $\mathbf{1 9 9 8}$ & $\mathbf{1 9 9 9}$ & $\mathbf{2 0 0 0}$ & $\mathbf{2 0 0 1}$ \\
\hline Croatia & 3.5 & 4 & 4 & 4 & 4 & 4 & 4 & 4 & 4 & 2.5 & 2 \\
\hline $\begin{array}{c}\text { Candidate } \\
\text { Country }\end{array}$ & $\mathbf{2 0 0 2}$ & $\mathbf{2 0 0 3}$ & $\mathbf{2 0 0 4}$ & $\mathbf{2 0 0 5}$ & $\mathbf{2 0 0 6}$ & $\mathbf{2 0 0 7}$ & $\mathbf{2 0 0 8}$ & $\mathbf{2 0 0 9}$ & $\mathbf{2 0 1 0}$ & $\mathbf{2 0 1 1}$ & $\mathbf{2 0 1 2}$ \\
\hline Croatia & 2 & 2 & 2 & 2 & 2 & 2 & 2 & 1.5 & 1.5 & 1.5 & 1.5 \\
\hline
\end{tabular}

Source: (Freedom House, 2014a)

Table 3 shows that 2000 was a very significant year regarding Croatia's democratization. That year, Freedom House changed Croatia's rating from 4 to 2 and its status from Partly Free to Free following the conduct of free and fair presidential and parliamentary elections, efforts to make the state media independent of government, and evidence that Croatia's new leaders were fulfilling promises for political, economic and social reform (Freedom House, 2001). Thus, Croatia became a liberal democracy according to Freedom House nearly five years before the EU started accession negotiations with it. These reforms and the country's subsequent cooperation with the ICTY marked a turning point in relations between the EU and Croatia. On the basis of these achievements, the EU decided to grant Croatia candidate status in July 2004 (European Commission, 2004, p. 6). After the start of the accession negotiations on October 3, 2005, Croatia continued to implement democratization reforms to get EU membership. In 2009, for example, improvements in the treatment of its minority Serb and Roma communities allowed Freedom House to change Croatia's rating from 2.0 to 1.5 (Freedom House, 2010a).

Currently, the EU has five candidate countries, namely Turkey, Montenegro, Serbia, Macedonia and Iceland. Of these, only Iceland has not faced political conditionality as it is already an advanced liberal democracy. However, the EU has also not imposed political conditionality as effectively on the current candidates as it did on the CEECs and Croatia. The reason for this lies first with the creation of the concept of "integration capacity", which means that the EU must first be able to function effectively at its present size before engaging in any further enlargement. Second, some EU member states, such as France, also now wish to hold referenda before accepting any further enlargements. These two developments 
have decreased the credibility of EU political conditionality on current candidate countries because they fear that they may not gain EU membership even if they fulfill the Copenhagen criteria (Schimmelfennig, 2011: 919). However, the EU has nevertheless managed to democratize many practices in these countries.

Turkey and the EU have longer history of relations than the other current candidates, starting with the signing of the Ankara Agreement in 1963. After 36 years of fluctuating relations, the EU declared Turkey as a candidate country in 1999, and on October 3, 2005, accession negotiations started. Serbia officially applied for EU membership in 2009. However, the EU demanded that it fully cooperate with the ICTY if it wanted to join the EU. After the capture of Ratko Mladić and Goran Hadžić, accused of crimes against humanity, war crimes and genocide, the EU granted Serbia candidate status in 2012. In 2013, the European Council announced that accession negotiations with Serbia will start by January 2014. Macedonia began its rapprochement with the EU in 2000 with negotiations on a Stabilization and Association Agreement (SAA), which was signed in April 9, 2001, and came into force on April 1, 2004, after three years of ratification process. Macedonia submitted its application for EU membership on March 22, 2004, and the European Council, after taking the positive opinion of the European Commission, granted it candidate status on December 17, 2005. However, accession negotiations have been delayed by Macedonia's ongoing disputes with Greece and Bulgaria. In 2006, the parliament of Montenegro proclaimed independence from the State Union of Serbia and Montenegro, before applying for EU membership two years later. The European Commission issued a positive opinion in 2010 regarding Montenegro's application. Accession negotiation with Montenegro finally started on June 29, 2012.

Table 4: Freedom House Ratings for Current Candidate Countries

\begin{tabular}{|c|c|c|c|c|c|c|c|c|c|c|c|c|}
\hline $\begin{array}{l}\text { Candidate } \\
\text { Country }\end{array}$ & $\bar{\sigma}$ & 亏ั & 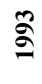 & 亏ั & 气̆ & よั & $\hat{\sigma}$ & $\stackrel{2}{\sigma}$ & 天े & ఃั & ฮั่ & ฮิ \\
\hline Turkey & 3 & 3 & 4 & 5 & 5 & 4.5 & 4.5 & 4.5 & 4.5 & 4.5 & 4.5 & 3.5 \\
\hline Montenegro & - & - & - & - & - & - & - & - & - & - & - & - \\
\hline Serbia & - & - & - & - & - & - & - & - & - & - & - & - \\
\hline Macedonia & - & 3.5 & 3 & 3.5 & 3.5 & 3.5 & 3.5 & 3 & 3 & 3.5 & 4 & 3 \\
\hline $\begin{array}{l}\text { Candidate } \\
\text { Country }\end{array}$ & 气ิ & : & 气ิ & ๕ั้ & ฮิ & $\stackrel{\infty}{\stackrel{\sim}{0}}$ & ڤ્ণ & 옥 & $\overline{\text { ป }}$ & ฮั) & 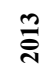 & \\
\hline Turkey & 3.5 & 3 & 3 & 3 & 3 & 3 & 3 & 3 & 3 & 3.5 & 3.5 & \\
\hline Montenegro & - & - & - & 3 & 3 & 3 & 2.5 & 2.5 & 2.5 & 2.5 & 2.5 & \\
\hline Serbia & - & - & - & 2.5 & 2.5 & 2.5 & 2 & 2 & 2 & 2 & 2 & \\
\hline Macedonia & 3 & 3 & 3 & 3 & 3 & 3 & 3 & 3 & 3 & 3 & 3 & \\
\hline
\end{tabular}

Source: (Freedom House, 2014a) 
The EU has had a significant impact on the democratization on many practices in Turkey. When Turkey was granted candidate status in 1999, as seen from Table 4, its democracy rating was 4.5. Due to political conditionality, Turkish governments adopted nine harmonization packages between February 2002 and July 2004, in addition to comprehensive constitutional amendments in 2001 and 2004. This EU-inspired democratization process allowed Freedom House to change Turkey's rating in 2002 from 4.5 to 3.5, due to an improved human rights framework and reduced restrictions on different cultures (Freedom House, 2003a). Freedom House further improved Turkey's rating in 2004, from 3.5 to 3, mentioning as contributing factors the complete overhaul of its penal code, greater civilian control of the military, the initiation of broadcasts in minority languages and a decrease in the severest forms of torture. Following these reforms, the EU rewarded Turkey by starting accession negotiations on October $3,2005 .{ }^{8}$ However, the definition in the Negotiation Framework Document of these negotiations as an "open-ended process", meaning that Turkey will not automatically become an EU member on their conclusion, and the EU's decision to suspend negotiations with Turkey on eight of 35 negotiation chapters in December $2006,{ }^{9}$ have significantly reduced Turkey's motivation to initiate further reforms. In 2012, Freedom House moved Turkey's rating back from 3 to 3.5 due to the pretrial detention of thousands of individuals, including activists, journalists, union leaders, students and military officers, in a series of criminal investigations and trials that many believe to be politically motivated (Freedom House, 2013a).

Serbia submitted its membership application to the EU in 2009. In the same year, Freedom House changed the country's rating from 3 to 2 due to the consolidation of a stable multiparty system after several rounds of elections in the post-Milosevic period (Freedom House, 2010b). A year after the signing of the SAA, in 2002, Macedonia introduced significant democratization reforms to satisfy the demands of the Albanian minority in line with the provisions of the Ohrid Framework Agreement (OFA), signed between the Macedonian government and ethnic Albanian representatives on August 13, 2001. The Macedonian government eliminated references in the constitution to Macedonia as "the land of the Macedonian people", while the Albanian language was made an official language in municipalities where Albanians comprise at least 20 percent of the population. These reforms allowed Freedom House to change Macedonia's rating from 4 to 3

\footnotetext{
${ }^{8}$ According to the ratings of Freedom House, among all former and current candidates, Turkey was the only exception as being Partly Free country before start of the accession negotiations.

${ }^{9}$ Turkey's reluctance to apply the Additional Protocol to the 1963 Ankara Agreement to Greek Cypriots led the European Council to suspend negotiations with Turkey on eight of 35 Chapters. These included Free Movement of Goods, Right of Establishment and Freedom to Provide Services, Financial Services, Agriculture and Rural Development, Fisheries, Transport Policy, Customs Union and External Relations. It was also stipulated that no chapter could be provisionally closed until Turkey fulfills all of its commitments.
} 
in 2002 (Freedom House, 2003b). Impressed by Macedonia's commitment to implementing the OFA, which significantly contributed to its satisfaction of the Copenhagen political criteria, the European Commission, on November 9, 2005, recommended that accession negotiations should be started (European Commission, 2005). In 2009, Freedom House changed Montenegro's rating from 3 to 2.5 due to its successful organization of parliamentary elections in March 2009, progress in adopting anti-corruption legislation and an overall stabilization of conditions (Freedom House, 2010c). Meanwhile, Montenegrin reforms in 2009 significantly encouraged the European Commission to issue a positive opinion the following year on opening accession negotiations.

\section{The Effectiveness of Political Conditionality on ENP's Southern Partners}

The main reason the EU has developed regional policies is to promote peace, economic development and prosperity. The EU considers that this can prevent threats such as terrorism, illegal immigration, drug and human trafficking related to its periphery countries from affecting Europe. In addition, the EU wants to increase the trade and investment opportunities of its economic actors (Smith, 2006: 6770). With this logic, the EU has created several regional policies, such as the 1972 Global Mediterranean Policy, the 1990 Renovated Mediterranean Policy, the 1994 European Economic Area, the 1995 Euro-Mediterranean Partnership (transformed into the Union for the Mediterranean in 2008), the 1999 Northern Dimension, the 2007 Central Asia Strategy, the 2008 Black Sea Synergy and the 2009 Eastern Partnership.

The CEECs accession to the EU in 2004 changed its borders and thus its neighbors, which brought both new challenges and new opportunities. Therefore, the EU, in addition to its existing regional policies, decided to create the ENP. At the Brussels European Council summit of December 12-13, 2003, EU leaders approved the "Wider Europe-Neighborhood: A New Framework for Relations with Our Eastern and Southern Neighbors", prepared by the European Commission. On May 12, 2004, the European Commission published the "European Neighborhood Policy Strategy Paper", the main document of the ENP. The ENP was offered to 16 non-candidate countries: Armenia, Azerbaijan, Belarus, Georgia, Moldova, Ukraine, Algeria, Egypt, Israel, Jordan, Lebanon, Libya, Morocco, Occupied Palestinian Territory, Syria and Tunisia. The ENP depends on bilateral treaties in which the EU takes into consideration each partner country's capacities and individual requirements. This bilateral approach makes the ENP different from the Union for the Mediterranean, which is mainly a multilateral policy.

With the introduction of the ENP, the EU wanted to offer privileged relations to its neighboring countries. The European Commission first published its Country Reports for partner countries. In these reports, the European Commission presented recommendations as to how to deepen relations by analyzing economic and political conditions of the partner countries. After this, Action Plans were prepared 
for partner countries that took into account the specific requirements of these countries. In the Action Plans, the EU decided the short- and long-term reforms (35 years) that it expected the partner countries to fulfill. So far, Action Plans have been implemented with Israel, Jordan, Moldova, Morocco, the Occupied Palestinian Territory, Tunisia and Ukraine since 2005, and Armenia, Azerbaijan, Georgia, Lebanon and Egypt since 2007. Due to their political problems, Action Plans have not been published for Algeria, Syria, Libya and Belarus. The European Commission also publishes annual Progress Reports for partner countries implementing the Action Plans. In order to improve the ability of the ENP to encourage democratization and socio-economic reforms, the EU introduced the European Neighborhood and Partnership Instrument (ENPI) in 2007 as the financial instrument of the policy, ${ }^{10}$ with 14.9 billion Euros allocated until 2013. In May 2010, Stefan Füle, the EU Commissioner for Enlargement and European Neighborhood Policy, announced his satisfaction with the financial dimension of the ENP, reporting that in the last five years EU exports to its ENP partners increased 63 percent while imports from these partners increased 91 percent. However, Füle also stated his dissatisfaction with the implementation of political reforms in partner countries (AB Haber, 2010).

Starting in late 2010, as a result of lingering economic problems, political pressures and corruption, citizens in several Arab states rebelled against their authoritarian governments, in a movement commonly called the Arab Spring. Their protests led to regime changes in Egypt, Tunisia and Libya, with narrower political reforms also being implemented in other Arab countries. In order to give a positive response to the Arab Spring, the EU had to revise the ENP. The new and ambitious ENP was put into practice by the EU on May 25, 2011, with the aim of taking significant steps to promote civil society and economic cooperation. However, the most important point of the new ENP was the introduction of an approach of "more funds for more reform" for partner countries in exchange for their introduction of democratic reforms. Stefan Füle summarized this approach as follows:

Increased EU support to its neighbors is conditional. It will depend on progress in building and consolidating democracy and respect for the rule of law. The more and the faster a country progresses in its internal reforms, the more support it will get from the EU (European Commission, 2011a).

By adopting this approach, it was clear that the EU aimed to increase the effectiveness of its political conditionality strategy on ENP partner countries.

The EU does not present a specific recipe or model for the reforms that ENP partner countries should execute. However, even though reforms differ in each country, the EU does require the development of liberal democratic values to deepen and sustain democracy in the partner countries, including free and fair elections, freedoms of assembly, association, press and expression, rule of law, right to a fair trial, efforts against corruption and democratic control of the armed

\footnotetext{
${ }^{10}$ With the introduction of the ENPI, the EU abolished its former instruments, the MEDA and TACIS.
} 
forces. The EU determines the amount of financial assistance to offer depending on how much partner countries introduce these liberal reforms (European Commission, 2011b: 3). However, there are two key weaknesses in the EU's political conditionality strategy that it has imposed on the ENP's Southern partners. Firstly, the EU's usage of political conditionality with the ENP's Southern partners does not include the incentive of EU membership. Therefore, these countries are neither excited nor enthusiastic so the EU's democratization efforts have so far failed. As Florent Parmentier puts it, without the 'golden carrot' of the incentive of EU membership, the EU's usage of political conditionality is merely "soft conditionality" (Parmentier, 2006: 3). In fact, the EU cannot possibly offer this incentive due to Article 49 of the Treaty on the European Union, which stipulates that a country wishing to apply for EU membership must be a European country. The second weakness in the EU's approach to ENP partners is that their governments have not suffered any domestic costs for non-compliance with EU political conditionality. That is, these governments have remained very relaxed because there have is neither societal (civil society) nor institutional (political parties) reform pressure in their countries supporting EU-demanded democratization reforms.

Table 5: Freedom Ratings for the ENP's Southern Partners

\begin{tabular}{|l|c|c|c|c|c|c|c|c|c|c|}
\hline $\begin{array}{l}\text { Partner } \\
\text { Country* }\end{array}$ & $\mathbf{2 0 0 4}$ & $\mathbf{2 0 0 5}$ & $\mathbf{2 0 0 6}$ & $\mathbf{2 0 0 7}$ & $\mathbf{2 0 0 8}$ & $\mathbf{2 0 0 9}$ & $\mathbf{2 0 1 0}$ & $\mathbf{2 0 1 1}$ & $\mathbf{2 0 1 2}$ & $\mathbf{2 0 1 3}$ \\
\hline Egypt & 5.5 & 5.5 & 5.5 & 5.5 & 5.5 & 5.5 & 5.5 & 5.5 & 5 & 5.5 \\
\hline Israel & 2 & 1.5 & 1.5 & 1.5 & 1.5 & 1.5 & 1.5 & 1.5 & 1.5 & 1.5 \\
\hline Jordan & 4.5 & 4.5 & 4.5 & 4.5 & 5 & 5.5 & 5.5 & 5.5 & 5.5 & 5.5 \\
\hline Lebanon & 5.5 & 4.5 & 4.5 & 4.5 & 4.5 & 4 & 4 & 4.5 & 4.5 & 4.5 \\
\hline Morocco & 4.5 & 4.5 & 4.5 & 4.5 & 4.5 & 4.5 & 4.5 & 4.5 & 4.5 & 4.5 \\
\hline $\begin{array}{l}\text { Palestinian } \\
\text { Authority- } \\
\begin{array}{l}\text { Administered } \\
\text { Territories }\end{array}\end{array}$ & 5.5 & 5 & 5 & 5.5 & 5.5 & 5.5 & 6 & - & - & \\
\hline West Bank* & - & - & - & - & - & - & - & 5.5 & 5.5 & 5.5 \\
\hline Gaza Strip** & - & - & - & - & - & - & - & 6 & 6 & 6.5 \\
\hline Tunisia & 5.5 & 5.5 & 5.5 & 6 & 6 & 6 & 6 & 3.5 & 3.5 & 3 \\
\hline
\end{tabular}

Source: (Freedom House, 2014a)

* Due to their political problems, the EU has not published Action Plans for Algeria, Libya and Syria. Thus, they are excluded from this table.

** Since 2011, Freedom House has scored the freedom ratings of the Palestinian territories with one report for the Gaza Strip and one for the West Bank.

Table 5 clearly shows that EU political conditionality has not promoted democratization in the ENP's Southern partner countries since its implementation in 2004. All partners, except Israel, are still rated as Partly Free or Not Free by Freedom House. For Egypt, the removal from power of the Supreme Council of the Armed Forces, which assumed power after the military coup that overthrew President Hosni Mubarak in 2011, and the subsequent presidential election that was almost close to international standards led to Freedom House in 2012 to 
improve the country's rating from 5.5 to 5 (Freedom House, 2013b). However, in 2013, because of the overthrow of the elected president, Mohamed Morsi, the military's increased political intervention, and bloody crackdowns on civil society and Islamist political groups, Freedom House reduced Egypt's rating to 5.5 again, placing it among not free countries (Freedom House, 2014b). Freedom House changed Jordan's rating from 4.5 to 5 in 2008 due to many arrests that brought into question citizens' rights to freedom of speech. These cases included a dual FrenchJordanian citizen accused of insulting the king and five journalists accused of insulting the judiciary and government officials (Freedom House, 2009). In 2009, Freedom House further worsened Jordan's rating to 5.5. This stemmed from King Abdullah's decision to dismiss the parliament and delay elections until the end of 2010, as well as the security forces' increasing influence in political life (Freedom House, 2010d). Freedom House improved Lebanon's rating from 4.5 to 4 in 2009 because of a reduction in the political violence that it had been severely suffering from since 2005, and the introduction of several reforms to overcome sectarianism and reduce arbitrary detention (Freedom House, 2010e). Lebanon's rating, however, returned to 4.5 in 2011 because of the government's violent reaction to demonstrators demanding the removal of Hezbollah-backed Najib Miqati as prime minister and government officials' arbitrary detentions of Syrian refugees calling for democratization in their own country (Freedom House, 2012b).

Turning to Morocco, there have been no changes in the ratings since the introduction of the ENP in 2004, with the country still rated as partly free, with 4.5 in 2013. It is not even an electoral democracy as most power is held by the king and his close advisers according to Freedom House reports, evaluated the situation in the Western Sahara separately. The main democratization challenges facing Morocco are as follows: harassment of nonviolent Islamist groups that criticize the monarchical system; structural corruption; punishment of journalists who criticize the king, his family and the country's Western Sahara policy; suspensions of broadcasting of several visual media and internet sites for critical coverage of the Western Sahara issue; intolerance of religious diversity including campaigns of arrests of Shiites and Muslim converts to Christianity; violent control of demonstrations, in particular those regarding the Western Sahara; and government domination of the judiciary (Freedom House, 2013c).

According to Freedom House, the West Bank and the Gaza Strip are not free, rated as 5.5 and 6.5 in 2013, respectively. In the West Bank, although President Mahmoud Abbas has made some improvements in recent years, corruption remains a significant problem. The media are not free in the West Bank as journalists can be easily jailed and newspapers easily closed if they publish secret information regarding the security of the Palestinian Authority. The West Bank also lacks religious freedom because the Basic Law defines Islam as the official religion, although the Basic Law requires the maintenance of respect and sanctity for Judaism and Christianity. Another major problem of democratization in the West Bank is that the judiciary is not independent. The existence of military courts with 
the authority to impose the death penalty is also a serious problem (Freedom House, 2013d).

Like the West Bank, the Gaza Strip also suffers significant problems of corruption, lack of media and religious freedoms, and a non-independent judiciary. However, it has worse democratization problems, stemming from Israel's economic blockade and the conflict between Hamas and Israel, which make life very hard for Gazans. Firstly, Hamas significantly restricts freedoms of association and assembly in the Gaza Strip. For instance, when nearly 500 people protested against Hamas after the death of a 3-year-old child in a fire in September 2012 in Bureij refugee camp, Hamas forces were quick to disperse the demonstration. In 2009, the conflict with Israel led Hamas officials to restrict the activities of aid organizations and close many civic associations. Secondly, Hamas security forces regularly violate human rights by arbitrary detentions and torture. Hamas also prevented the Independent Commission for Human Rights, a Palestinian human rights ombudsman agency, from entering Gaza's central prison and Hamas detention centers. Thirdly, economic freedom and choice are severely affected by Israel's blockade of Israel, with the only way for Gazans to facilitate economic activity beyond Gaza being the use of tunnels, which are frequently bombed by Israeli Air Forces, between the Gaza Strip and Egypt. Finally, Gazan women suffer stark discrimination in matters of divorce, marriage and inheritance because Sharia is the main source of the Personal Status Law (Freedom House, 2013e).

The only Southern partner of the ENP that has come close to being rated as free is Tunisia, although it is worth mentioning here that the Tunisia's improved ratings, from 6 to 3.5 in 2011 and 3 in 2013, did not result from the EU's usage of political conditionality. Rather, this stemmed from the positive impact of the Arab Spring in Tunisia. Specifically, the removal of the country's longtime dictator, Zine el-Abidine Ben Ali, in January 2011 paved the way for the introduction of democratization reforms, with free and fair elections for a transitional Constituent Assembly being held in October of the same year. The new government also managed to increase freedoms of speech, press, assembly, religious expression and academia in the same year (Freedom House, 2012c). Tunisia further introduced democratization reforms in 2013 that increased academic freedom, permitted the establishment of new labor unions and lifted travel restrictions (Freedom House, 2014c).

\section{Conclusion}

This paper analyzed the effectiveness of EU political conditionality on former and current candidates and ENP's Southern partners as measured by changes in Freedom House's democracy ratings for these countries. The analysis shows that the EU used political conditionality effectively on CEECs after the introduction of the Copenhagen political criteria in 1993. Except the Czech Republic and Hungary, whose ratings remained same before and after the EU introduced political criteria, before the start of accession negotiations all acceding CEECs of 2004 were liberal 
democracies according to Freedom House. Among these CEECs, however, Latvia, Estonia and Slovakia were particular success stories for the EU. Because, defined as only Partly Free countries before the creation of the Copenhagen political criteria, they became liberal democracies before starting the accession negotiations. As part of the 2004 enlargement, Bulgaria and Romania, the remaining CEECs, joined the EU in 2007. As with the other CEECs in 2004, EU, through political conditionality, strongly encouraged both of these countries' democratization, in particular Romania's. While Romania's rating was 4 before the Copenhagen political criteria were created in 1993, defined as a Partly Free country, its rating has improved to 2.5 by 1996 , defined as a liberal democracy, a year before the European Commission adopted Agenda 2000 in 1997, in which it recommended that accession negotiations with Romania could start, together with other CEECs. EU political conditionality had a transformative impact on Croatian democracy as well. Due to its democratization reforms before applying for EU membership, Croatia was rated by Freedom House as a liberal democracy in 2000, almost five years before the start of accession negotiations, and introduced further democratization reforms during its accession negotiations process. Consequently, Freedom House almost rated it as among the freest countries shortly before its accession to the EU.

Regarding the current candidates, it is possible to say that the EU has achieved the democratization of many practices through political conditionality, notably in the areas of protecting human rights, minority rights and different cultures. However, political conditionality has not been as effective as it was with the former candidate countries. For instance, Turkey and Macedonia are still only Partly Free countries according to Freedom House. This is mainly the result of the EU's new "integration capacity" approach, which has discouraged the current candidates from initiating further reforms. The credibility of political conditionality strongly depends on the EU's presentation of an obvious membership incentive. Thus, the EU should consider abolishing this approach if it wants to promote liberal democratic values throughout Europe.

The EU has been ineffective to promote democratization in any of its ENP's Southern partner countries through political conditionality since the creation of the ENP in 2004. The main reasons for this failure are the lack of any prospect of EU membership for ENP's Southern partner countries and the lack of domestic costs for their governing regimes for non-compliance. These two factors have made EU political conditionality a defunct strategy. Thus, the EU did not manage to impose its maximalist (liberal) perception of democracy on these countries, which still remain, according to Freedom House, either not free (Egypt, Jordan, the West Bank and the Gaza Strip) or partly free (Morocco, Lebanon and Tunisia, though the latter, significantly affected by the Arab Spring, made democratization reforms). This failure suggests that, instead of political conditionality, the EU should try other policies for promoting democratization in its Southern partners. First, the EU should abandon its contradictory democratization discourses 
regarding Arab countries. In particular, there is a serious contradiction in the EU's relative silence regarding the lack of democratization in oil-rich Arab countries, such as Saudi Arabia, the United Arab Emirates Qatar, Kuwait and Bahrain, which diminishes the credibility of its more vocal criticisms of other Arab states. Second, because radical Islamists have significant influence with the people in Arab countries, the EU should support their integration into legal politics, which would melt their power and soften their views about the EU (Boubekeur, 2009: 5-8). Third, the EU's Delegations in Southern partners, by establishing new institutions under their structures, can develop mass educational activities to enlighten civil society institutions regarding the EU's liberal democratic values and the European experience of democracy. 


\section{References:}

'AB Komşuluk Politikalarının Bilançosundan Memnun Değil', (2010), AB Haber, http://www.abhaber.com/ozelhaber.php?id=6283, Retrieved on: January 26, 2012.

Boubekeur, A., (2009), 'Updating the European Union's Policies Towards Islamist Parties and Radical Actors', International Institute for Democracy and Electoral Assistance, http://www.idea.int/resources/analysis/upload/Boubekeur_low_2.pdf, Retrieved on: June 25,2012

Delegation of the European Union to Croatia., (2013), Overview of EU-Croatia Relations, http://www.delhrv.ec.europa.eu/?lang=en\&content=62, Retrieved on: October 30, 2013.

Diamond, L., (1999), Developing Democracy: Toward Consolidation, Johns Hopkins University Press, Baltimore and London.

Diamond, L., (2003), 'Universal Democracy', Policy Review, June-July 2003, No. 119 pp. 3-26.

'EU Parliament: Ukraine, Moldova and Georgia May Apply to Join EU', Europe without Barriers, http://novisa.org.ua/en/yevroparlament-u-rezolyutsiyi-pidtverdiv-perspektivuchlenstva-ukrayini-v-yes/, Retrieved on: June 27, 2014.

European Commission, (2004), Opinion on Croatia's Application for Membership of the European Union, http://eurlex.europa.eu/LexUriServ/site/en/com/2004/com2004_0257en01.pdf, Retrieved on: October 31, 2013.

European Commission, (2005), Commission Opinion on the Application from the former Yugoslav Republic of Macedonia for Membership of the European Union, http://eurlex.europa.eu/smartapi/cgi/sga_doc?smartapi!celexplus!prod!CELEXnumdoc\&lg=en\&n umdoc $=505 \mathrm{DC} 0562$, Retrieved on: November 5, 2013.

European Commission, (2011a), A New and Ambitious European Neighborhood Policy, $\mathrm{http}$ //europa.eu/rapid/pressReleasesAction.do?reference=IP/11/643\&format=HTML\&a ged $=0 \&$ language $=$ EN\&guiLanguage $=$ en, Retrieved on: July 28, 2012.

European Commission, (2011b), A New Response to a Changing Neighborhood: A Review of European Neighborhood Policy, http://ec.europa.eu/world/enp/pdf/com_11_303_en.pdf, Retrieved on: January 26, 2012.

European Council, (1993), Presidency Conclusions, European Council in Copenhagen, June 21-22, SN 180/1/93 REV 1.

Freedom House, (2001), Freedom in the World 2001- Croatia, http://www.freedomhouse.org/report/freedom-world/2001/croatia, Retrieved on: October 31, 2013.

Freedom House, (2003a), Freedom in the World 2003- Turkey, http://www.freedomhouse.org/report/freedom-world/2003/turkey, Retrieved on: November 6, 2013.

Freedom House, (2003b), Freedom in the World 2003- Macedonia, http://www.freedomhouse.org/report/freedom-world/2003/macedonia, Retrieved on: November 5, 2013. 
Freedom House, (2009), Freedom in the World 2009- Jordan, http://www.freedomhouse.org/report/freedom-world/2009/jordan\#.U6p4mfl_tKA, Retrieved on: June 26, 2014.

Freedom House, (2010a), Freedom in the World 2010- Croatia, http://www.freedomhouse.org/report/freedom-world/2010/croatia, Retrieved on: October 30, 2013.

Freedom House, (2010b), Freedom in the World 2010- Serbia, http://www.freedomhouse.org/report/freedom-world/2010/serbia, Retrieved on: November 6, 2013.

Freedom House, (2010c), Freedom in the World 2010- Montenegro, http://www.freedomhouse.org/report/freedom-world/2010/montenegro,Retrieved on: November 6, 2013.

Freedom House, (2010d), Freedom in the World 2010- Jordan, http://www.freedomhouse.org/report/freedom-world/2010/jordan\#.U6p7avl_tKA, Retrieved on: June 26, 2014.

Freedom House, (2010e), Freedom in the World 2010- Lebanon, http://www.freedomhouse.org/report/freedom-world/2010/lebanon\#.U6qACfl tKA, Retrieved on: June 26, 2014.

Freedom House, (2012a), Freedom in the World 2012: The Arab Uprisings and Their Global Repercussions, http://www.freedomhouse.org/sites/default/files/FIW\%202012\%20Booklet_0.pdf, Retrieved on: July 28, 2012.

Freedom House, (2012b), Freedom in the World 2012- Lebanon, http://www.freedomhouse.org/report/freedom-world/2012/lebanon\#.U6qPl_1_tKA, Retrieved on: June 26, 2014.

Freedom House, (2012c), Freedom in the World 2012- Tunisia, http://www.freedomhouse.org/report/freedom-world/2012/tunisia-0, Retrieved on: November 5, 2013.

Freedom House, (2013a), Freedom in the World 2013Turkey,http://www.freedomhouse.org/report/freedom-world/2013/turkey, Retrieved on: November 6, 2013.

Freedom House, (2013b), Freedom in the World 2013- Egypt, http://www.freedomhouse.org/report/freedom-world/2013/egypt\#.U6pwC_1_tKA, Retrieved on: June 26, 2013.

Freedom House, (2013c), Freedom in the World 2013- Morocco, http://www.freedomhouse.org/report/freedom-world/2013/morocco\#.U6qnJvl_tKA, Retrieved on: June 26, 2013.

Freedom House, (2013d), Freedom in the World 2013- West Bank, http://www.freedomhouse.org/report/freedom-world/2013/west-bank\#.U6vqVP1_tKA, Retrieved on: June 27, 2013.

Freedom House, (2013e), Freedom in the World 2013- Gaza Strip, http://www.freedomhouse.org/report/freedom-world/2013/gaza-strip, Retrieved on: June 27, 2013. 
Freedom House, (2014a), Country Ratings and Status, 19732014,http:/www.freedomhouse.org/report-types/freedom-world\#.U6f3Lfl_tKA, Retrieved on: June 23, 2014.

Freedom House, (2014b), Freedom in the World 2014- Egypt, http://www.freedomhouse.org/report/freedom-world/2014/egypt-0\#.U6pykfl_tKA, Retrieved on: June 23, 2014.

Freedom House, (2014c), Freedom in the World 2014- Tunisia, http://www.freedomhouse.org/report/freedom-world/2014/tunisia-0\#.U6vs5P1_tKA, Retrieved on: June 27, 2014.

Nobel Prize, (2012), The Nobel Peace Prize for 2012, http://www.nobelprize.org/nobel_prizes/peace/laureates/2012/press.html, Retrieved on: October 24, 2013.

Kausch, K., \& Youngs, R., (2009), 'The End of the Euro-Mediterranean Vision', International Affairs, Vol. 85, No. 5, pp. 968- 969.

Kubicek, P. J., (2003), 'International Norms, the European Union and Democratization: Tentative Theory and Evidence,' in Paul. J. Kubicek, (Ed.) The European Union and Democratization, Routledge, London.

Parmentier, F., (2006), 'The European Neighborhood Policy as a Process of Democratic Norms Diffusion in Ukraine. Can the EU Act Beyond Conditionality', Center for European Studies,http://www.cee.sciences-po.fr/erpa/docs/wp_2006_2.pdf, Retrieved on: November 28, 2013.

Schimmelfenning, F., (2005a), 'European Neighborhood Policy: Political Conditionality and its Impact on Democracy in Non-Candidate Countries', Paper prepared for the EUSA Ninth Biennial International Conference, Austin, 31 March- 2 April, http://aei.pitt.edu/3302/, Retrieved on: October 24, 2013.

Schimmelfenning, F., Engert, S., \& Knobel, H., (2005b), 'The Impact of EU Political Conditionality', in Frank Schimmelfenning\& Ulrich Sedelmeier, (Ed.)The Europeanization of Central and Eastern Europe, Cornell University Press, Ithaca and London.

Schimmelfenning, F., (2011), 'EU Political Accession Conditionality after the 2004 Enlargement: Consistency and Effectiveness', Journal of European Public Policy, Vol.15, No.6, pp. 918- 937.

Smith, K. E., (2006), European Union Foreign Policy in a Changing World, Polity Press Cambridge and Malden.

Stokke, O., (1995), Aid and Political Conditionality: Core Issues and State of the Art, Aid and Political Conditionality, Frank Cass, London.

Y1ldız, U. B., (2012), 'The European Union and Democratic Consolidation in Turkey: The Impacts and Limits', in Müge Aknur (Ed.), Democratic Consolidation in Turkey, Universal Publishers, Florida. 